\title{
sciendo
}

\section{LAND USE AND LANDSCAPE PATTERN CHANGES ON THE INSIDE AND OUTSIDE OF PROTECTED AREAS IN URBANIZING SELANGOR STATE, PENINSULAR MALAYSIA}

\author{
WoON HANG LEE ${ }^{1}{ }^{*}$, SAIFUl ARIF ABDUllaH ${ }^{1}$, SHUKOR BIN Md NoR ${ }^{2}$ \\ ${ }^{I}$ Institute for Environment and Development (LESTARI), Universiti Kebangsaan Malaysia, \\ 43600 UKM Bangi, Selangor, Malaysia,e-mail: saiful_arif2002@yahoo.com. \\ ${ }^{2}$ School of Environment and Natural Resources, Faculty of Science and Technology, \\ Universiti Kebangsaan Malaysia, 43600 UKM, Bangi, Selangor Darul Ehsan, Malaysia, \\ e-mail: shukor@ukm.edu.my. \\ *Corresponding author e-mail: nicole_kwy@yahoo.com
}

Received: $23^{\text {th }}$ October 2018 , Accepted: $22^{\text {th }}$ May 2019

\begin{abstract}
Unabated land use changes in developing countries have imperilled the urban ecosystem resilience. An urban protected area is one of the critical systems to absorb disturbance regimes in the metropolitan area, but it is increasingly pressured by urbanization. Therefore, assessing their land use and landscape pattern changes are pivotal to identify the conservation capacity. We developed land use maps for Klang Gate, Bukit Kutu, and Sungai Dusun wildlife reserves to assess their spatial and temporal land use changes between 1988 and 2012. The degree of fragmentation, the intensity of human impact and structural connectedness for these wildlife reserves were also quantified. The findings revealed that Klang Gate which located adjacent to the highly urbanizing area experienced a very significant loss of forest while built-up area and commercial agriculture gradually encroached into the reserve. It also has a higher degree of fragmentation and human impact than the other two reserves. Human impact inside of Klang Gate was concomitant to the outside. However, Bukit Kutu almost undisturbed and Sungai Dusun was slightly intruded by commercial agriculture. The results help different stakeholders, such as managing authorities and policy planners to strategize new land use planning that utilize limited land-based resources for future economic and social development. As the findings showed that urban protected areas alone are not sufficient in maintaining the urban ecosystem; therefore new conservation planning that integrates other urban green spaces at their surrounding is critical to ameliorating the conservation on a long-term basis.
\end{abstract}

Keywords: Urban protected area, ecological integrity, land use change, sustainable development, remote sensing, GIS

\section{INTRODUCTION}

Protected areas are not just protecting the environment and natural resources, but also accelerating economic development and achieving sustainable development (Wei et al., 
Lee W. H., Abdullah S.A., Nor S.B.M.: Land use and landscape pattern changes on the inside and outside of protected areas in urbanizing Selangor State, Peninsular Malaysia

2015). For example, protected areas in categories V and VI support nature conservation and also contribute to the welfare of the local community through the provision of natural products (Dudley \& Stolton, 2008). Protected areas remain as one of the urban most essential strategies for biodiversity conservation because they serve to preserve the natural landscape, wildlife habitats and facilitate species persistence within urban landscapes (Savard et al., 2000). Urban protected areas also provide a wide range of urban ecosystem services supplying and storing clean water, improving air quality, carbon sink, mitigating carbon dioxide emission and moderating the urban heat island effect (Defries et al., 2007; Mcpherson et al., 1997). Hence, urban protected areas contribute to "green infrastructure" within cities that ameliorate urban living quality in terms of physical or emotional health (IUCN, 2005; Trzyna 2014).

However, human population growth leads to rapid urban expansion which necessitates a significant threat to the protected areas (Castro-prieto et al., 2017). Increasing migration from rural to urban areas has to speed up urban sprawl and create a mixture of the developed regions and a remnant of native vegetation (Blair, 2004). It affects the spatial heterogeneity of urban ecosystems (Alberti \& Marzluff, 2004) through homogenizing species composition and native species replaced by non-native species (Hansen \& Defries, 2007a; Mckinney, 2002). In this context, protected areas in an urbanizing region are one of the nearest systems that can absorb the disturbance regimes that occur within it. It also refers to protected areas' capacity to mitigate disturbance regimes such as land use development, for ecosystem resilience in the urbanizing region (Alberti \& Marzluff, 2004; Estevo et al., 2017, Holling, 1973). Theoretically, we should have more intensive monitoring and quick institutional actions to any indication of unsustainable development. Intriguingly, however, the opposite trend appears to be occurring in many urban societies, with even more fierce competition between environmental conservation and anthropogenic resource demands. As a result, it created threats to urban biodiversity and its associated elements and thus reduced the urban ecosystem resilience.

Generally, the level of urbanization in Malaysia increased from about $28.4 \%$ in 1970 to $61.8 \%$ in 2000 (Yaakob et al., 2012), and is expected to exceed $70 \%$ by 2020 (Ho, 2008). Meanwhile, there is also a trend of rapid population growth at the suburb areas where in some cases higher than the metropolitan area itself (Masron et al., 2012). At the same time, the migration of rural people to the urbanizing areas increases speedily (Bunnell \& Barter, 2002; Yaakob et al., 2012). Forest loss also occurred at a fast rate and it causes protected areas increasingly resemble islands in an extensive sea of development.

Thus, a doubt arises regarding the capacity of protected areas for ecosystem resilience in the urbanizing regions, which refers to the capacity of a system to absorb disturbances and changes, while maintaining its functions and structures. Here, capacity is determined by the landscape pattern of the protected areas and its surrounding, spatially and temporally (Bailey et al., 2016; Hansen \& Defries, 2007b). The landscape patterns include the naturalness and fragmentation state of the protected areas, and also its connectedness with habitat patches on the surrounding. The landscape pattern on its surrounding is vital because land use changes resulted from urban expansion may degrade ecological integrity between inside and outside protected areas (Bailey et al., 2016; Hansen \& Defries, 2007a). Furthermore, previous studies also demonstrate intensive land use has recently increased around protected areas globally (Castro-prieto et al., 2017; Leroux \& Kerr, 2012).

In this regard, how landscape patterns of protected areas change in the rapidly urbanizing process, particularly in developing countries? To address the question, the level of fragmentation, naturalness, and connectedness of protected areas and its $5 \mathrm{~km}$ zone outside were quantified, in Selangor State, Peninsular Malaysia across 24 years, that is, between 
1988 and 2012. The objective is to understand how they are fair for ecosystem resilience in urbanizing Selangor State.

\section{MATERIALS AND METHODS}

\section{Study area}

In this study, we selected three protected areas in Selangor State - Klang Gate, Sungai Dusun, and Bukit Kutu wildlife reserves. Klang Gate wildlife reserve (hereafter referred to as Klang Gate) located in Gombak district but adjacent to Kuala Lumpur City (Fig. 1). Klang Gate is not a big protected area as its size is only 1348 ha. It is part of the catchment area of Klang Gate reservoir (Perumal, 1992) and it supported Klang Gate quartz ridge more than 14 $\mathrm{km}$ long and $200 \mathrm{~m}$ wide. The quartz ridge is one of the unique and outstanding geological formations in Peninsular Malaysian that endowed with diverse species of flora and fauna (Razak et al., 2015; Wong et al., 2010).

Sungai Dusun wildlife reserve (hereafter referred to as Sungai Dusun) and Bukit Kutu wildlife reserve (hereafter referred to as Bukit Kutu) are located about $100 \mathrm{~km}$ and $80 \mathrm{~km}$ to the north of Kuala Lumpur city, respectively (Fig. 1). Almost every part of Sungai Dusun located in Hulu Selangor district and only a small portion in Kuala Selangor district. This reserve is the largest protected area in Selangor State (i.e., covered a total area of 5113 ha) and characterized by the presence of fresh water peat swamp forest. Bukit Kutu located in Hulu Selangor district and its total area is 1845 ha. It is perched on the Titiwangsa Range which featured by a mixture of lowland and hill dipterocarp forest and the elevation ranges from 250 meters to the highest peak at 1053 meter a.s.l. (Lim et al. 1999).

\section{Data source}

A 1988 land use map of Klang Gate, Sungai Dusun and Bukit Kutu and their 5km surrounding was obtained from Institute for Environment and Development (LESTARI), Universiti Kebangsaan Malaysia. They are images of Landsat Thematic Mapper (TM) with a 30 m resolution. Studies from Reza et al. (2013) and Reza (2014) were also processing and analyzing the same maps. Meanwhile, SPOT 5 images with a $10 \mathrm{~m}$ resolution which obtained from the Malaysian Remote Sensing Agency (MRSA) were processed through ERDAS Imagine 9.1 to develop 2012 land use maps for each protected areas and zones $5 \mathrm{~km}$ outside of the sites (refer to Image pre-processing and Image classification and accuracy assessment sections).

\section{Image pre-processing}

The SPOT 5 satellite images for Selangor state were mosaicked and we subset the selected protected areas in Selangor state. These images were geo-corrected to align with the GCS Kertau coordinate system and image enhancement was performed to improve visual interpretation. Furthermore, bands of spectral data were combined to generated band combinations that enhance clarification and differentiation of various land uses of interest. A false colour composite of band combination 4-3-2 was applied to the images. 
Lee W. H., Abdullah S.A., Nor S.B.M.: Land use and landscape pattern changes on the inside and outside of protected areas in urbanizing Selangor State, Peninsular Malaysia

Fig. 1: Location of the three wildlife reserves in Selangor State

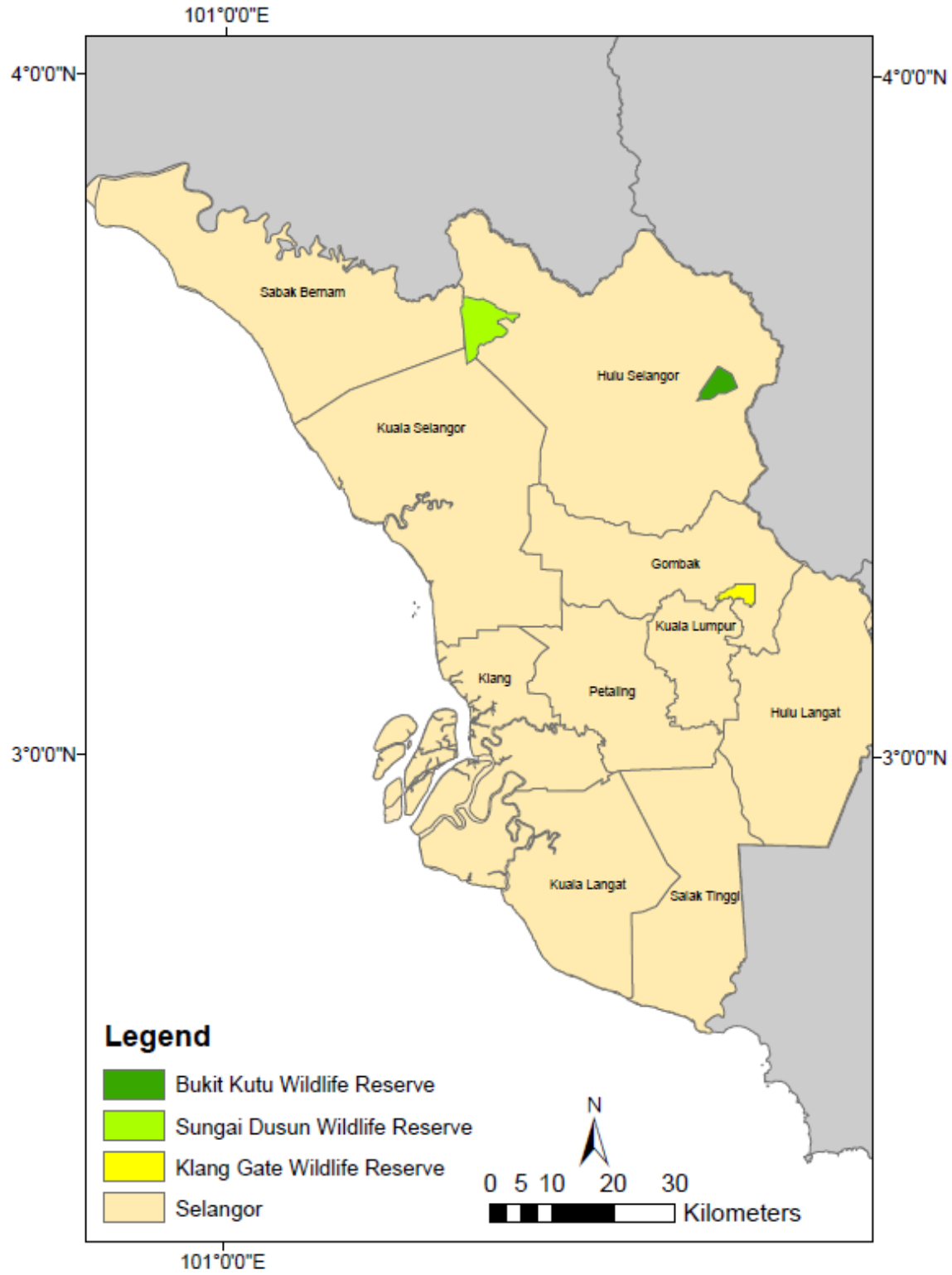

\section{Image classification and accuracy assessment}

The images were classified using supervised classification that was carried out through Maximum Likelihood (MAXLIKE) algorithm technique, in which the classification is primarily controlled by the analyst (Butt et al., 2015, Eastman, 2001). The land use classifications for the 1988 Landsat TM imagery included: built-up area, bare land, commercial agriculture, paddy and other agriculture, water body, and forest. The same classification was used for the 2012 SPOT 5 imagery. 
The accuracy assessment was carried out to validate the accuracy of supervised classification through the testing of these classifications with the reference pixels or values. Since the user has trained the software to recognize the specific colour tone and pixel value during the supervised classification for each land use class, the software itself was commanded to generate a set of reference pixel (ERDAS Inc., 1999; Islam et al., 2018). In this assessment, a stratified random sampling scheme was applied in which a total of 256 points were randomly generated for each supervised classification image (i.e., Klang Gate, Bukit Kutu, and Sungai Dusun). User identified and assigned these points with their respective land use class, and eventually these points were considered as classified values.

The confusion matrix (error matrix) method was used to statistically compare the classified data and the reference data with the help of other existing reference maps such as topographic maps of 2012 (scale 1:50,000) and the land use maps of Selangor State produced by Department of Agriculture Malaysia in 2012 (scale 1:200,000). As such, the confusion table showed the overall accuracy ( $p o$ ) and the kappa coefficient $(k)$. Kappa is a quantitative measure of the magnitude of agreement between predefined producer ratings and the user assigned ratings (Cohen, 1960; Viera \& Garrett, 2005). Kappa coefficient values, $k$, is between 0 and 1, where 1 indicates perfect agreement while 0 indicates agreement equivalent to chance (Viera \& Garrett, 2005). Basically, the level of agreement $>0.8$ is almost perfect (Landis \& Koch, 1977) and it depicts that the classification procedure is acceptable to finalize the land use classes. The po and k values for Klang Gate ( $p o-88.3 \% ; k-0.84)$, Bukit Kutu (po-87.5\%; $k-0.82)$ and Sungai Dusun po-83.6 \%; $k-0.80)$ were reliable to be used in landscape pattern analysis.

\section{LANDSCAPE PATTERN ANALYSIS}

The classified images were analyzed using ArcGIS 10. To account for differences in the spatial resolution of the 1988 (30 m resolution) and 2012 (10 m resolution) maps, 2012 data were resampled using the nearest neighbour algorithm to a $30 \mathrm{~m}$ resolution. Then, we overlaid the digitized boundaries of Klang Gate, Bukit Kutu, Sungai Dusun and their $5 \mathrm{~km}$ zones outside on the land use maps (vector format) and we clipped the boundaries on the map. Finally, 1988 and 2012 land use maps of Klang Gate, Bukit Kutu and Sungai Dusun and their $5 \mathrm{~km}$ zone outside (hereafter referred to as outside) were produced and subsequently used in the landscape pattern analyses - fragmentation, hemeroby, and connectedness analyses.

\section{Fragmentation analysis}

Fragmentation was analyzed using GUIDOS toolbox, a standalone freeware (European Commission, 2019). It uses Morphological Spatial Pattern Analysis (MSPA) to classify landscape pattern change resulted from fragmentation process by performing a segmentation of image objects into seven different and mutually exclusive geometric categories: core, islet, loop, bridge, perforation, edge, and branch (Soille \& Vogt, 2009; Wickham et al., 2010). The definitions of each category were recorded in Clay et al. (2016). Firstly, ArcGIS 10 was used to create an input layer that matched the format required by GUIDOS toolbox to run MSPA analysis (Clay et al., 2016; Vogt, 2015). The raster layers of each study site were first reclassified to contain a value of ' 1 ' for cells represent non-natural areas, for example, human-modified areas (background for the MSPA analysis) and a value of ' 2 ' for cells represent all natural areas, for example, forested areas or water bodies (foreground for the MSPA analysis). Then, these reclassified binary raster layers were exported to an 8-bit GeoTiff format with no compression to run an MSPA batch process. The results from MSPA 
Lee W. H., Abdullah S.A., Nor S.B.M.: Land use and landscape pattern changes on the inside and outside of protected areas in urbanizing Selangor State, Peninsular Malaysia

in GeoTiff format were converted back to raster layers to calculate the area (i.e., size) and percentage of each fragmentation category. Finally, the degree of fragmentation on the inside and outside of each protected area was quantified through equation (1) (Lee \& Abdullah, 2019):

$F=100-[C-(I+P+E+B+R+L)]$

where $F$ is the percentage of total fragmentation; $C$ denotes the percentage of the core area; $I, P, E, B, R$, and $L$ represent the percentage of the islet area, perforated area, edge area, branch area, bridge area, and loop area, respectively. An $F$ value of 100 indicates the highest fragmentation, whereas 0 implies that the protected area is fragmentation free.

\section{Hemeroby analysis}

Hemeroby predominantly attempts to measure the land use intensity and transformation of landscape patterns that have an impact on habitat and the organisms (Steinhardt et al., 1999; Fu et al., 2006). There are seven hemeroby degrees according to the intensity of human impacts: oligohemerobe, mesohemerobe, euhemerobe, polyhemerobe, metahemerobe (started from lowest to highest strength) and ahemerobe (no human impact) (Steinhardt et al., 1999; Walz \& Stein, 2014). However, only the first six categories were taken into consideration in the calculation except ahemerobe. The definition of an undisturbed Earth's land surface environment (i.e., not influenced by the human impact) is a place where there is no light emission visible from the spacecraft and there was no road or major river within 15 kilometers. We believe that some degree of human impact exists almost everywhere; therefore practically strict criteria of ahemerobe does not exist in Peninsular Malaysia. Equation (2) was applied to evaluate the values of hemeroby (e.g. Steinhardt et al., 1999, Walz \& Stein, 2014):

$M=100 \sum_{h=1}^{m} \frac{f_{m}}{m} h$

where $m$ is the number of hemeroby categories, $f_{m}$ is the proportion of the area of the category $m$, and $h$ is the hemeroby linear factor (i.e., $h=1$ for minimal $h=m$ for maximum). $M$ equals to 100 if the entire area is classified as metahemeroby, which indicates that the area encountered excessively strong human impact and it is mainly covered by the artificial environment.

\section{Connectedness analysis}

This analysis quantified structural connectedness on the inside (i.e., the connectedness of land use adjacent to protected areas' border) and outside (i.e., connectedness between the border of $5 \mathrm{~km}$ zone and its adjacent land uses). It examines how far these borders connected to the natural or non-natural environment. Higher connectedness with natural vegetation implies better ecological flows and processes. As such, a grid layer with $100 \mathrm{~m} \times 100 \mathrm{~m}$ dimension was created and overlaid on the inside and outside of each protected area. The grid squares on the borders were selected to measure connectedness. For each grid box, if the area outside the border has more than $50 \%$ of natural land use (i.e., forest and water bodies), they are considered connected with the natural land uses and assigned as ' 1 '. Otherwise, it is given ' 0 ' if the outside area has less than $50 \%$ of natural land uses, in which it is associating with a non-natural area (i.e., commercial agricultural, paddy or other agricultural lands, bare land and built-up area). The same procedure was applied to the outside. The overall connectedness was calculated using equation (3) (Lee \& Abdullah, 2019): 
$C=\frac{a}{N} \times 100$

where $C$ represents the connectedness value, $a$ is the total grids which yield value ' 1 ', and $N$ is the total number of grid box on the border.

\section{RESULTS}

\section{Land use change}

\section{Klang Gate}

The 1988 and 2012 land use distributions for Klang Gate are shown in Fig. 2a and 2b, respectively. Forest dominated the land use in Klang Gate for both years, with $87.2 \%$ in 1988 and $57.3 \%$ in 2012. In 1988, the percentage of water bodies was almost $12 \%$ whereas the remaining land uses - bare land and built-up area - represented less than $2 \%$ of the total land use (Fig. 3a). However, in 2012, the built-up area became the second highest land use $(15.6 \%)$ followed by commercial agriculture (13.3\%) and the water body (12.8\%) (Fig. 3a).

Land use classes outside were the same as the inside (Fig. 2c and 2d). In both years, the outside was mainly covered by forest $(1988-66.2 \%$ and $2012-45.3 \%$ ) (Fig. 3b). Forest coverage was followed by the built-up area, which was $18.9 \%$ in 1988 and $40.1 \%$ in 2012 . Generally, the proportion of forest on the outside reduced while the built-up area increased. The least portion was shown by other land uses - water bodies, commercial agriculture and, paddy and other agriculture. These land-uses increased slightly during the study period while bare land reduced (Fig. 3b).

Fig. 3: Percentage of each land use type for Klang Gate on the inside (a) and outside (b)

(a)

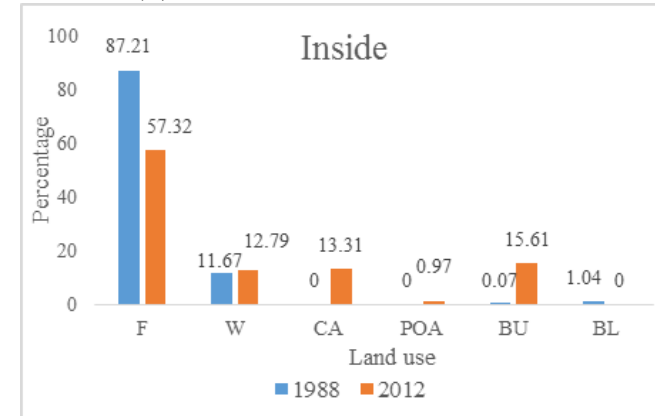

*Note: $\mathrm{F}$ - forest, $\mathrm{W}$ - Water body, CA - Commercial agriculture, POA - Paddy and other agriculture, BU - Built-up area, BL - Bare land. (b)

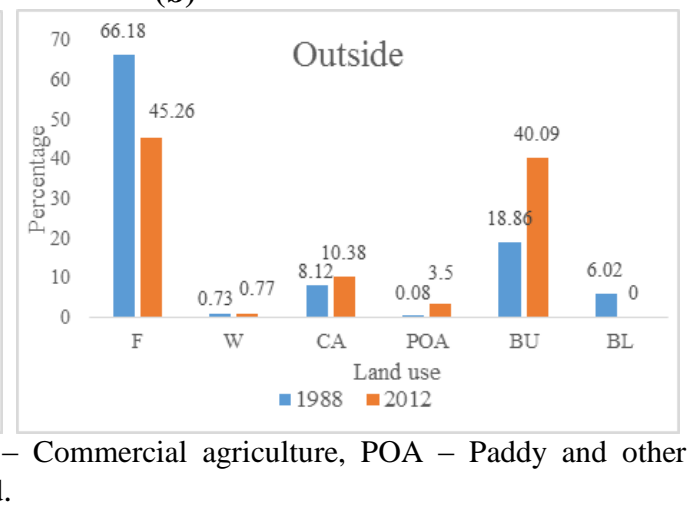


Lee W. H., Abdullah S.A., Nor S.B.M.: Land use and landscape pattern changes on the inside and outside of protected areas in urbanizing Selangor State, Peninsular Malaysia

Fig. 2: Land use map for Klang Gate at 1988 (a), 2012 (b), and land use outside of Klang Gate at 1988 (c) and 2012 (d).

(a)

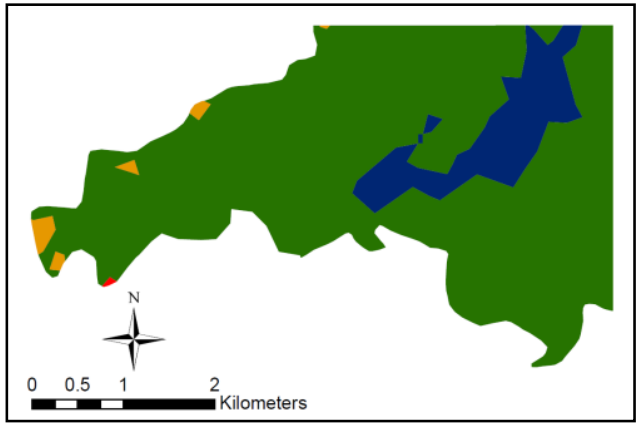

(c)

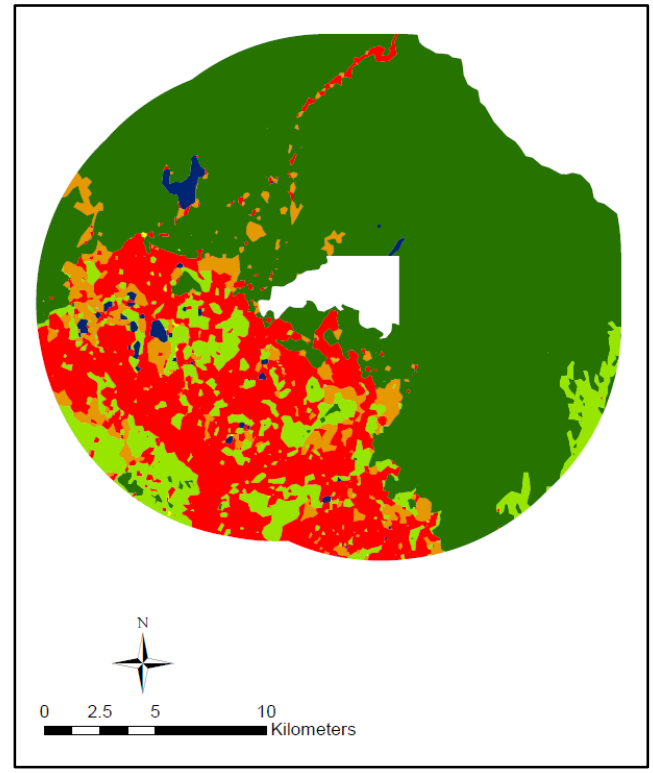

(b)

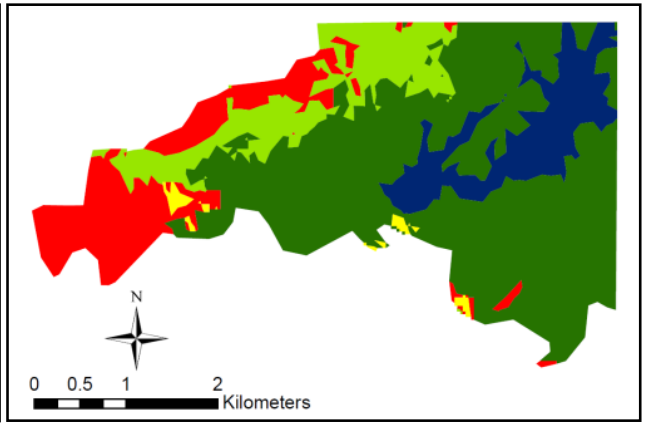

(d)

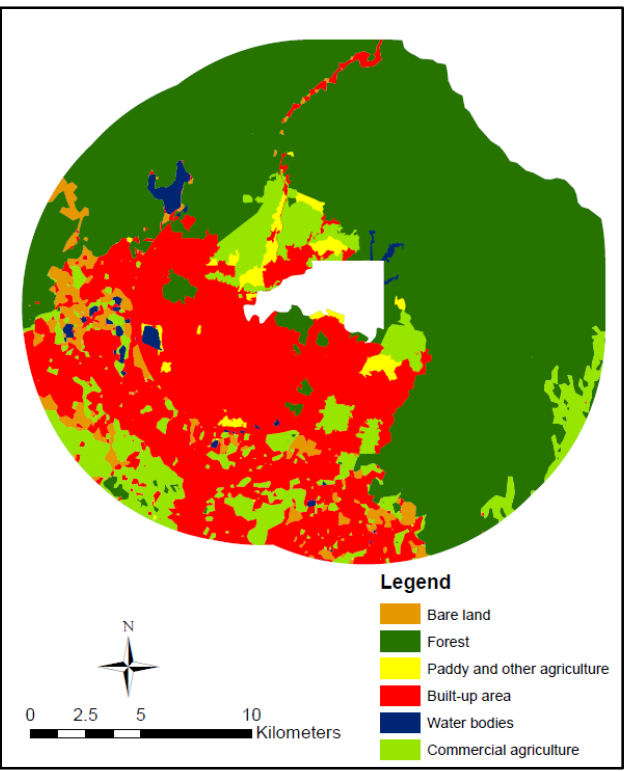

\section{Bukit Kutu}

The land use distribution on the inside of Bukit Kutu in 1988 and 2012 are shown in Fig. 4a and $4 \mathrm{~b}$, respectively. In 1988, the forest was the only land use identified in Bukit Kutu, but forest cover reduced slightly to $98.4 \%$ in 2012 (Fig. 5a). In 2012, a very least proportion of built-up area and water bodies emerged on the inside (Fig. 5a). On the outside (Fig. 4c, 4d), the forest was the dominated land use in 1988 (80.5\%) but reduced to $69.7 \%$ in 2012 (Fig. $5 b)$. In 1988 , about $16 \%$ on the outside covered by commercial agriculture which increased marginally in $2012(17.8 \%)$. Other land uses were small in proportion for both years (Fig. $5 b)$. 
Fig. 4: Land use map for Bukit Kutu at 1988 (a), 2012 (b), and land use outside of Bukit Kutu at 1988 (c) and 2012 (d).

1988

(a)

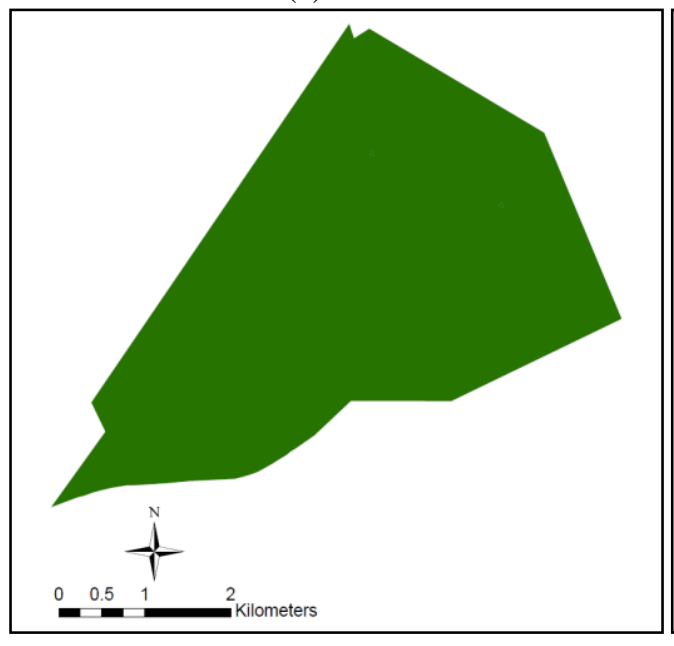

(c)

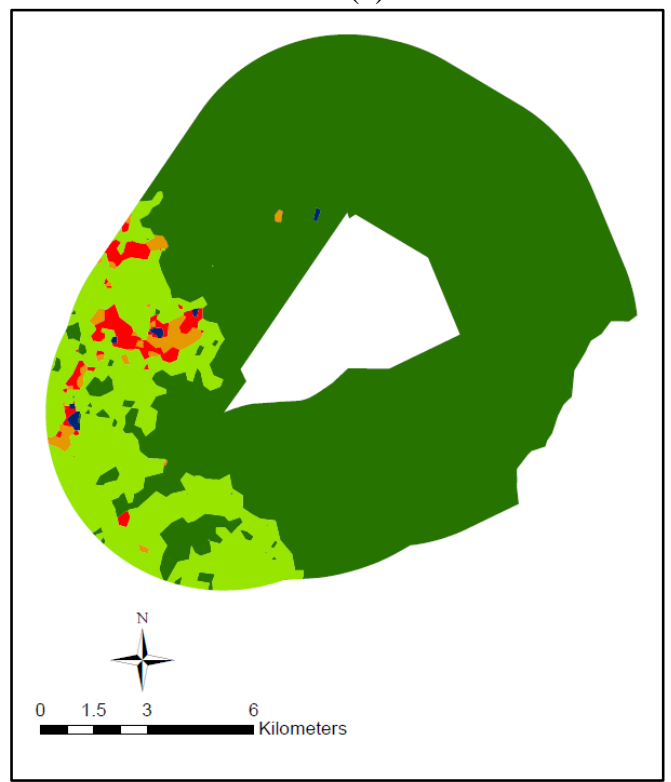

2012

(b)

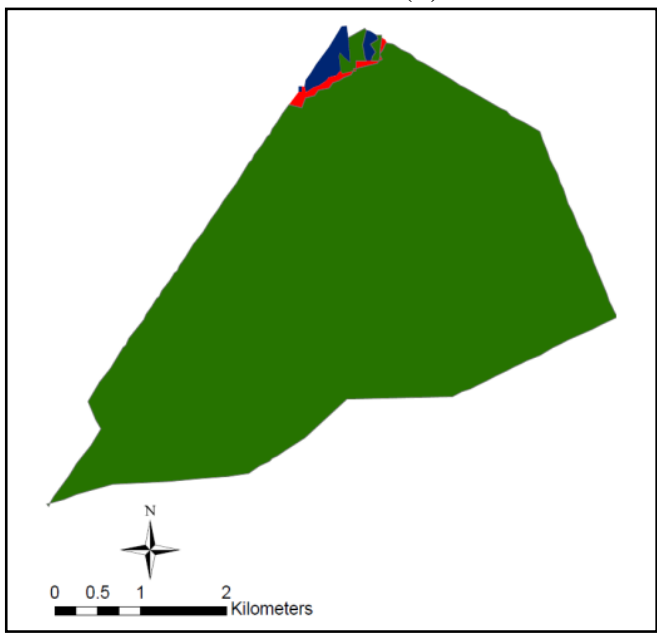

(d)

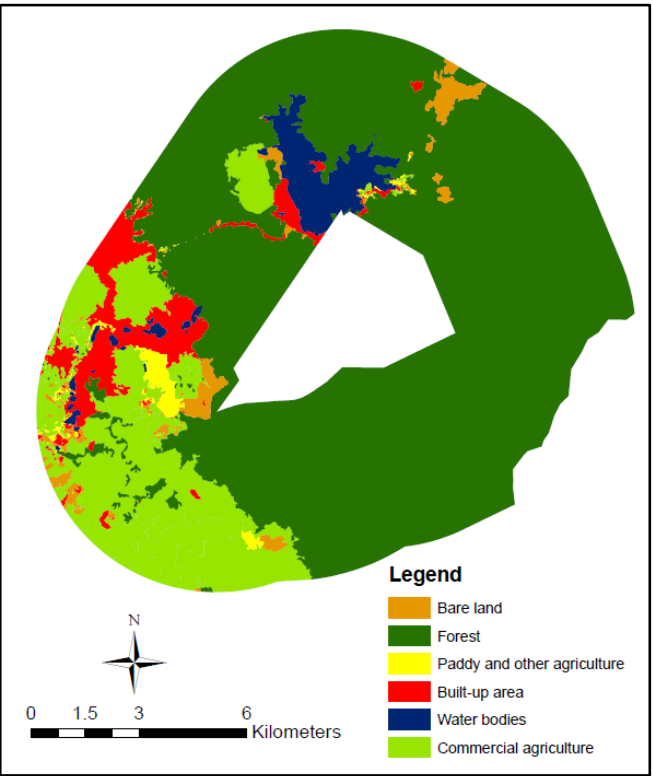


Lee W. H., Abdullah S.A., Nor S.B.M.: Land use and landscape pattern changes on the inside and outside of protected areas in urbanizing Selangor State, Peninsular Malaysia

Fig. 5: Percentage of each land use type for Bukit Kutu on the (a) inside and (b) outside

(a)

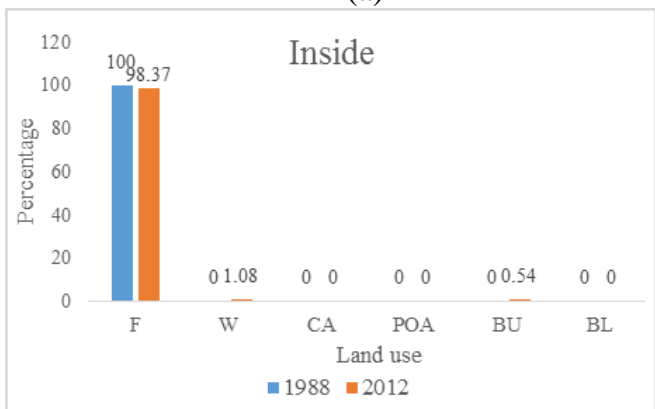

(b)

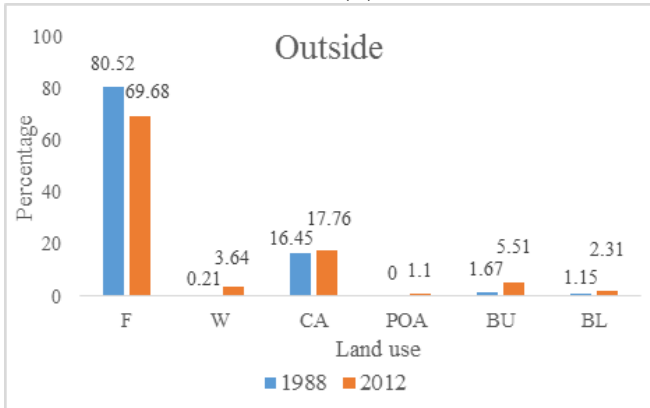

*Note: $\mathrm{F}$ - forest, $\mathrm{W}$ - Water body, CA - Commercial agriculture, POA - Paddy and other agriculture, BU - Built-up area, BL - Bare land.

\section{Sungai Dusun}

In 1988, only forest and commercial agriculture were identified on the inside (Fig. 6a). Sungai Dusun was covered by $98 \%$ forest whereas commercial agriculture was about $2 \%$. (Fig. 7a). In 2012, Sungai Dusun still dominated by forest $(93 \%)$ while commercial agriculture increased to $6.8 \%$ and $0.2 \%$ of the built-up area emerged (Fig. 6b, 7a). In 1988, the outside also mostly covered by forest $(77.3 \%$ ) but it reduced to $61.6 \%$ in 2012 (Fig. 6c, 7b). Commercial agriculture expanded from $22.3 \%$ in 1988 to almost $33 \%$ in 2012 (Fig. 6d). Generally, the other land uses were less than $10 \%$ in both years, but the trend increased throughout the study period (Fig. 7b).

Fig. 7: Percentage of each land use type for Sungai Dusun on the (a) inside and (b) outside

(a)

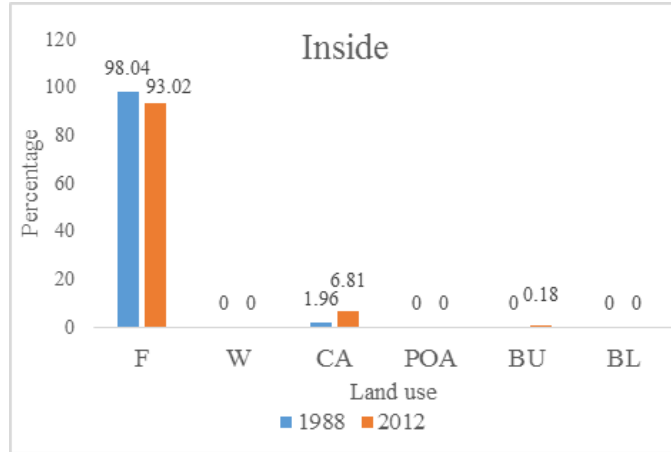

*Note: $\mathrm{F}$ - forest, W - Water body, CA - Commercial agriculture, POA - Paddy and other agriculture, BU - Built-up area, BL - Bare land. (b)

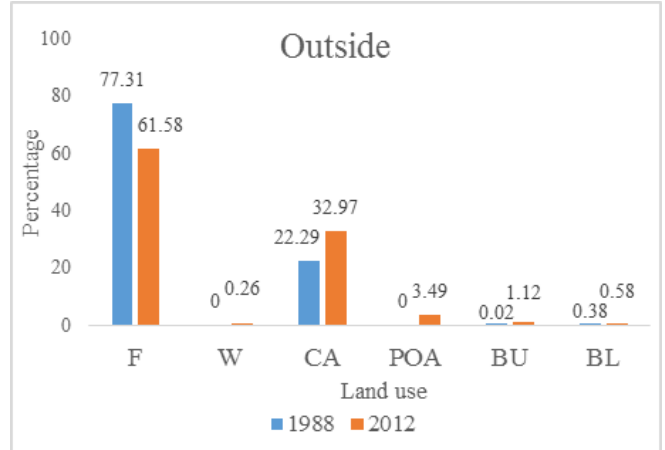


Fig. 6: Land use map for Sungai Dusun at 1988 (a), 2012 (b), and land use outside of Sungai Dusun at 1988 (c) and 2012 (d)

1988

(a)

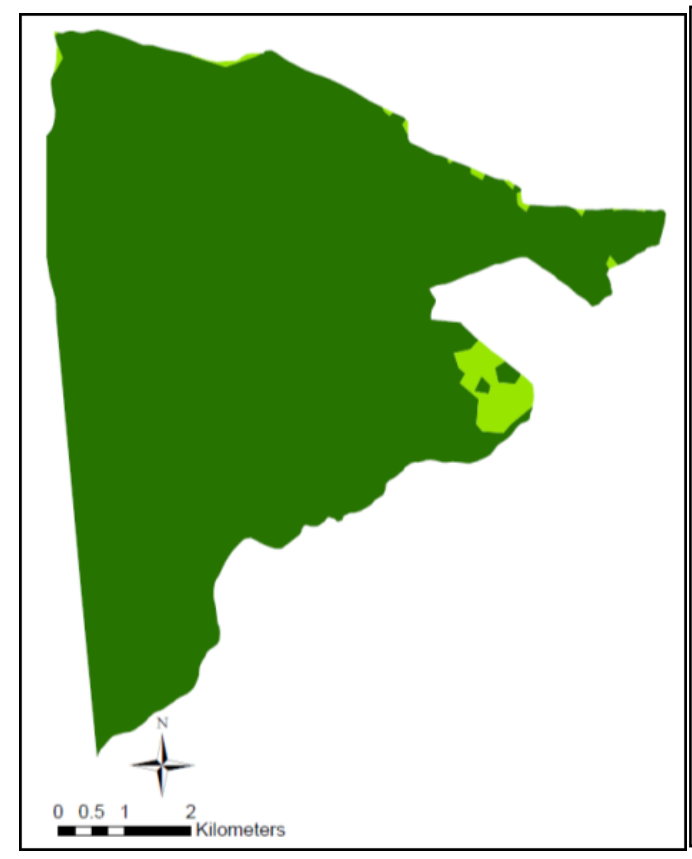

(c)

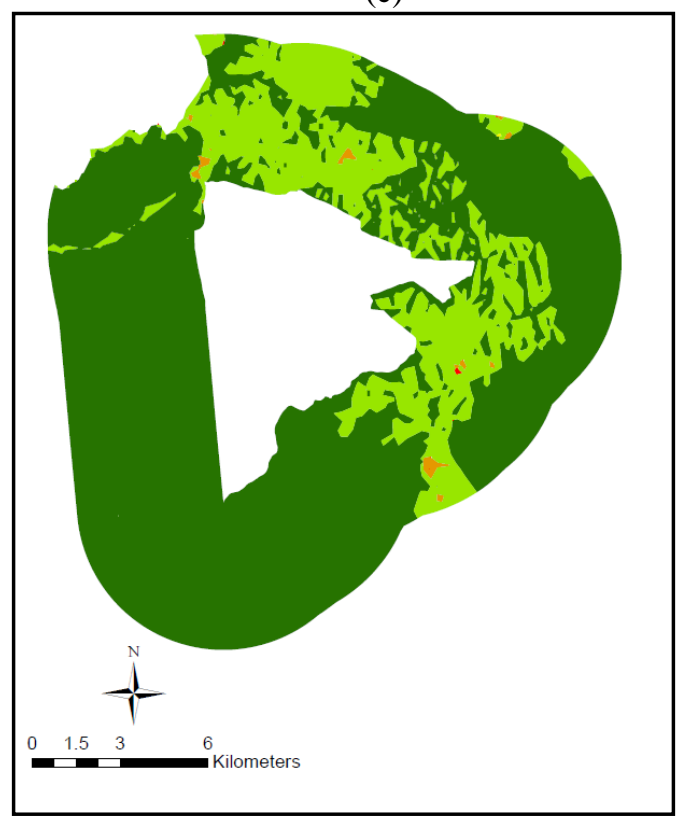

2012

(b)

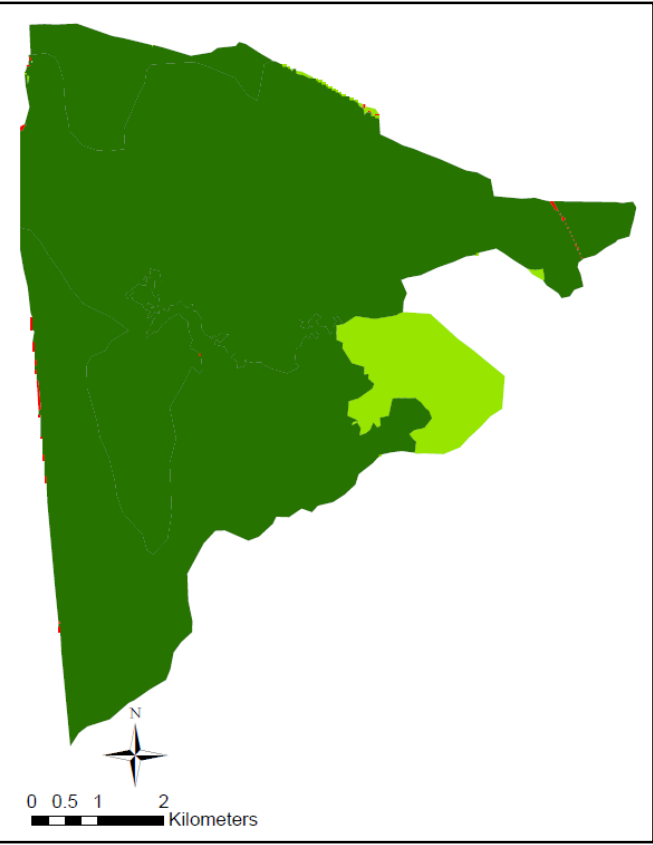

(d)

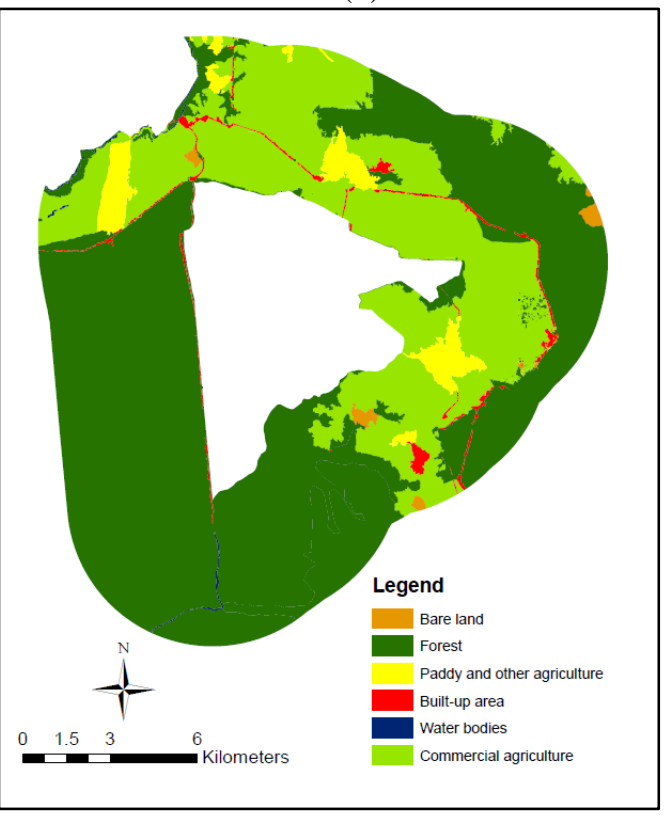


Lee W. H., Abdullah S.A., Nor S.B.M.: Land use and landscape pattern changes on the inside and outside of protected areas in urbanizing Selangor State, Peninsular Malaysia

\section{Landscape pattern change}

\section{Fragmentation}

The fragmentation inside Klang Gate increased from $7.1 \%$ to $35.4 \%$ during the study period (Fig. 8a). The outside also showed a similar trend but higher than the inside in both years. Fragmentation trends inside and outside Bukit Kutu and Sungai Dusun also similar to Klang Gate (Fig. 8b, 8c). However, fragmentation inside and outside of Bukit Kutu in 1988 and 2012 was generally lower than Klang Gate and Sungai Dusun. Fragmentation outside Sungai Dusun was not much difference with Klang Gate in both years (Fig. 8c), while fragmentation inside was almost similar with Klang Gate in 1988 but far less in 2012 (Fig. 8c).

Fig. 8: Fragmentation on the inside and outside of Klang Gate (a), Bukit Kutu (b), and Sungai Dusun (c).

(a)

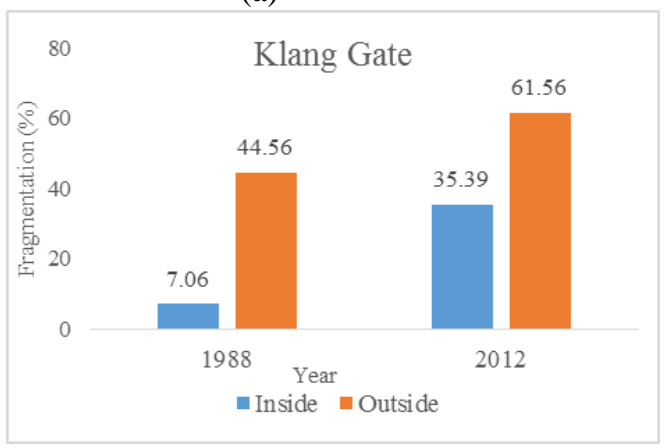

(c)

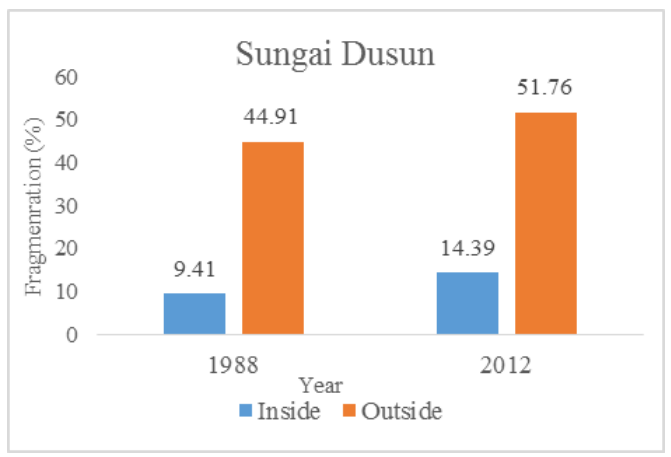

(b)

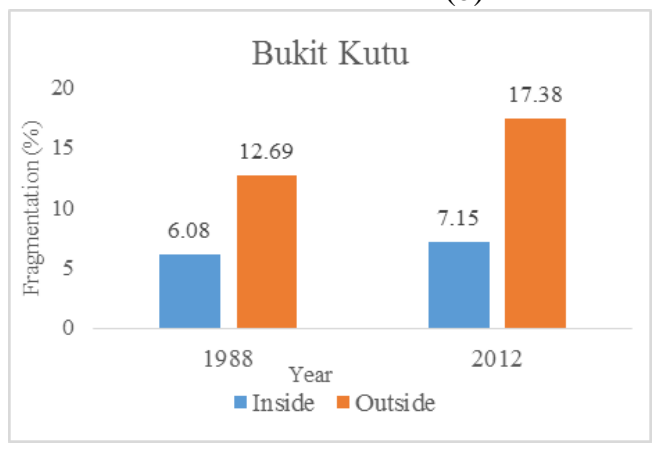

\section{Hemeroby}

Hemeroby index increased from 1988 to 2012 for both inside and outside of each reserve (Fig. 9a-c). The highest was Klang Gates whereas Bukit Kutu and Sungai Dusun almost similar. The highest increase over the 24 -year period was also Klang Gate $-15.3 \%$ inside and $14.3 \%$ outside (Fig. 9a). Hemeroby index on the inside and outside Bukit Kutu increased only less than $1 \%$ and $5.8 \%$, respectively (Fig. 9b). Meanwhile, Hemeroby index for Sungai Dusun increased $2.9 \%$ on the inside and $4.6 \%$ on the outside (Fig. 9c). 
Fig. 9: Hemeroby index at the inside and outside of (a) Klang Gate, (b) Bukit Kutu, and (c) Sungai Dusun.

(a)

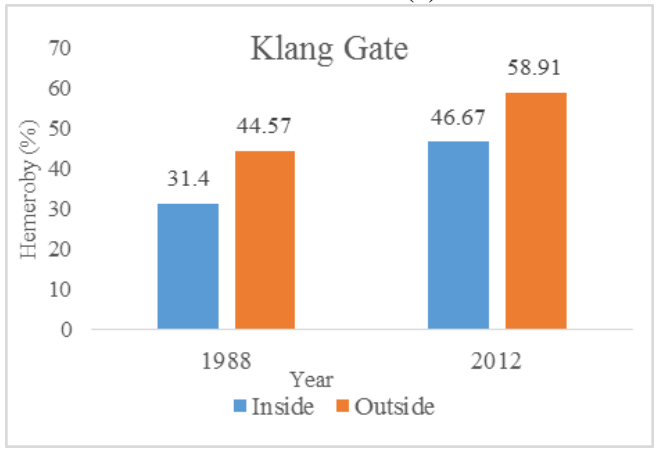

(c) (b)

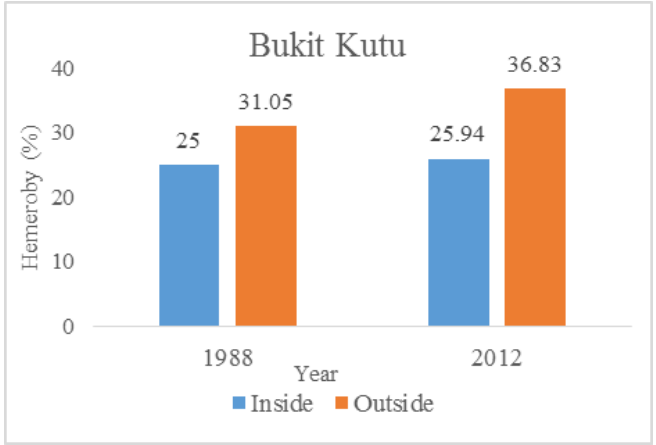

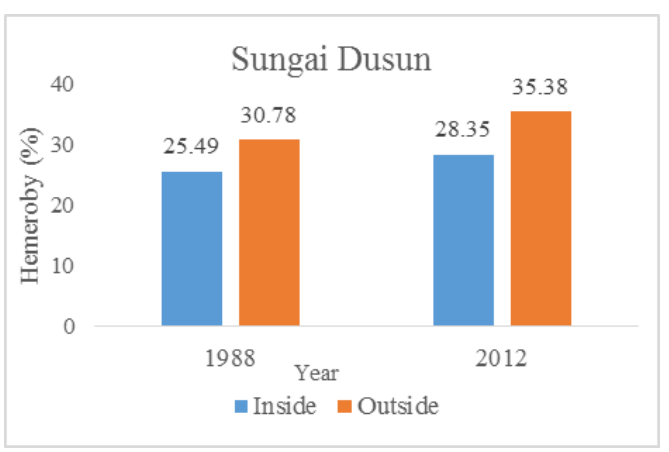

\section{Connectedness}

In 1988, Klang Gate, Sungai Dusun, and Bukit Kutu have very high connectedness level, which were $92.7 \%, 86.9 \%$, and $100 \%$, respectively (Fig. 10a-c). In 2012, the connectedness dropped noticeably in Klang Gates (42.7\%) and Sungai Dusun $(53.3 \%)$ but only slightly in Bukit Kutu (92.6\%) (Fig. 10a-c). In 1988, the outside connectedness was clearly less than the inside for Klang Gates (62.3\%) and Bukit Kutu (66.2\%). However, it was not much difference for Sungai Dusun $(83.1 \%)$. Generally, the connectedness outside Klang Gates and Bukit Kutu in 2012 were not much different from the outside in 1988 but slightly less in Sungai Dusun (Fig. 10a-c). But in 2012, the connectedness outside Klang Gates and Sungai Dusun was much higher than the inside. 
Lee W. H., Abdullah S.A., Nor S.B.M.: Land use and landscape pattern changes on the inside and outside of protected areas in urbanizing Selangor State, Peninsular Malaysia

Fig. 10: Connectedness on the inside and outside of Klang Gate (a), Bukit Kutu (b) and Sungai Dusun (c).

(a)

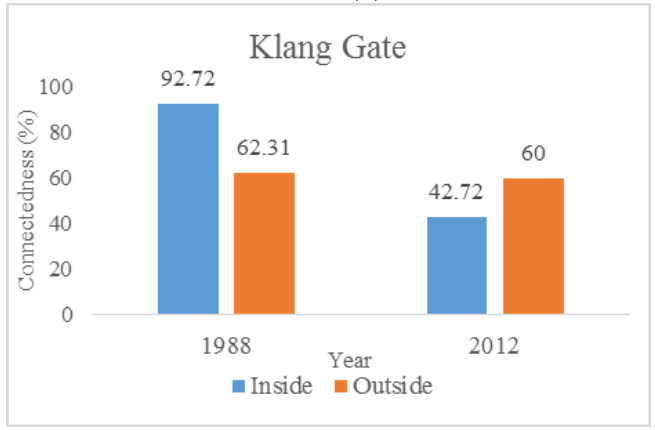

(c)

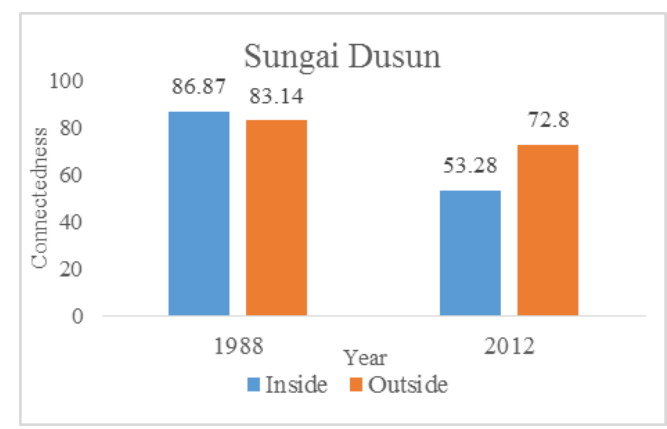

(b)

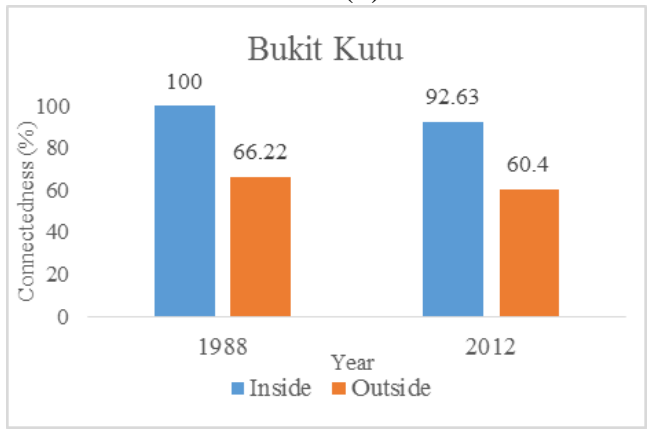

\section{DISCUSSION}

Land use change data is an imperative source for environmental monitoring, forecast of natural disaster, global environmental change, and facilitate planning and utilization of land and other natural resources (Hassan, 2017; Shaharum et al., 2018). Land use maps of the protected areas can serve as a useful input to the Department of Wildlife and National Park of Peninsular Malaysia (DWNP) in conservation planning and managing the sites.

The findings demonstrated that Bukit Kutu was relatively undisturbed probably due to its remoteness and hilly characteristics. The nearest town for this reserve is Kuala Kubu Bharu, which is a small town with low population density. Therefore, urbanization and human pressure are relatively lower. Some studies also supported that remoteness of protected areas can prevent pervasive human impacts and development within their boundaries (e.g. Butchart et al., 2012; Leroux \& Kerr, 2012).

For Sungai Dusun, commercial plantation slightly encroached to its east side. This trend is concomitant to the outside of Sungai Dusun. This is because the northern and eastern part of this reserve is surrounded intensively by oil palm plantation and it spreads gradually to the reserve. Nevertheless, population around this reserve was low, mainly settlements under the Federal Land Development Authority (FELDA) schemes, which opened up new lands and relocated landless smallholder farmers to urban settlements in order to carry out commercial agricultural farming (Olaniyi et al., 2013; Yaakob et al., 2012). 
On the other hand, Klang Gate experienced significant forest loss in the study period while built-up area and commercial agriculture infringed gradually to the reserve's core. These changes were concomitant to the changes on the outside. Our analysis was not designed to identify the causes and mechanisms of increasing land use change and development within and around protected areas; however, there are likely several factors at play. For example, economic factors in Selangor promote new residential developments in Kuala Lumpur. Many studies proved that land use and landscape pattern change, including the protected area systems (Terra et al., 2014) have a substantial link to socio-economic considerations and land development policies (Abdullah \& Hezri, 2008; Gallant et al., 2004). In Peninsular Malaysia, land development accentuated on agricultural growth in the years after national independence and then on manufactural expansion in the 1980s. In the era of agricultural expansion, rubber and oil palm plantations were most aggressively took place in many states of Peninsular Malaysia, including Selangor. It followed by the new economic development wave that favoured on the manufacturing sector which sped up land development for other land uses, such as housing, new urban areas and industrial estates. Furthermore, the growth of population density and the trend of migration from a rural area to urban resulted in the mounting of urban housing development, shifting the natural landscape to residential expansion, and consequently affecting the integrity of protected areas (Bunnell \& Barter, 2002; Reza, 2014; Yaakob et al., 2012). Due to the location of Klang Gate that is adjacent to urban development, it is more vulnerable to threats of land use changes.

Besides, natural amenities of Klang Gate (e.g., climate regulation, physical recreational site and urban infrastructure) have potentially attracted high rates of population growth and eventually increase the economic values of nearby real estate compared to real estate elsewhere. Hence, the distance between protected areas and cities is predicted to shrink dramatically (Mcdonald et al., 2008). Apart from the increased human pressures on the periphery of protected areas, recent studies also prove that global protected areas are undergoing different extents of downgrading in legal protection, downsizing of space, and degazettement of legally protected areas (Mascia et al., 2014). These situations have a strong tendency to degrade biodiversity, ecosystem function, and the ecosystem services supplied by the protected areas.

The results of our study indicate a more intense land use change occurred on the inside and outside of Klang Gate and Sungai Dusun compared to Bukit Kutu. These changes could link to the increasing landscape fragmentation and hemeroby in these protected areas that necessitate the reduction of connectedness with adjacent natural habitat. When fragmentation happens, forest density and core area (i.e. the interior forest patch) shrink, perforation increases (Riitters et al., 2002) and thus, widens the edge width surrounding the core area, and causes habitat loss and isolation (Andren, 1994; Fahrig, 2003; Wickham et al., 2010). High fragmentation degree on the inside and outside of Klang Gate coincides with a higher hemeroby value. This condition implies greater cumulative effects of landscape pattern change on environmental status, which resulted in a decrease of nature accentuated surfaces (Fu et al., 2006, Rüdisser et al., 2012). Consequently, structural discontinuity of habitat patches occurred due to the effects of land development, habitat fragmentation and other human intervention (Hill et al., 2011). Klang Gate and Sungai Dusun underwent substantial loss of connectedness and their values are lower than the values on the outside. This situation could be linked to the condition whereby development and land use modification in the areas outside of both protected areas are more localized and concentrated. However, development and plantation are rapidly spreading at the edge of inside Klang Gate and Sungai Dusun.

As such, land use intensification and habitat modification within and surrounding the protected areas alter not only the structural and compositional elements of landscape and 
Lee W. H., Abdullah S.A., Nor S.B.M.: Land use and landscape pattern changes on the inside and outside of protected areas in urbanizing Selangor State, Peninsular Malaysia

biodiversity, but also the ecological functions and processes (Hansen et al., 2005). For example, the escalating rate of fragmentation and development create new forest edges and detach patches from the continuous forest tract (Fahrig, 2003; Hill et al., 2011). Ecological effects originated from edges between forest and non-forest areas create edge effects and alter biophysical features for species, such as radiation, wind and water fluxes and therefore, lead to microclimate change (Estreguil \& Mouton, 2009; Sauders et al., 1991). Previous studies on mammal species richness in Selangor state also recorded the absence of large carnivore or top predator (e.g., Malayan Tiger and Melanistic Leopard) both in the contagious forest and fragmented urban forest reserves (Adila et al., 2017; Tee et al., 2018). Because most of the large mammals in the tropics such as rhinoceroses, tigers and elephants, are unlikely to persist in the multiple-use matrix that are subjected to anthropogenic disturbance (Lynam, 2010; Pattanavibool \& Dearden, 2002). Pfeifer et al. (2017) also shown that fragmented forest patches with sharp edges reduce forest-core habitats and in turn threatening those highly edge-sensitivities species, particularly prevalent among forest-core mammals and birds, and consequently, they can be diminished.

Furthermore, habitat loss surrounding protected areas in a rapidly urbanizing region could reduce the connectivity of habitat patches which deteriorate the linkages for species to move, migrate, disperse and genetic exchange with neighbouring sources (McDonnell \& Stiles, 1983). Hostile land uses adjacent to the protected areas are likely to reduce spatial heterogeneity at the surrounding and cause the lack of natural habitats that can serve as 'stepping stones' or corridors between separated forest patches (Fu et al., 2006; Heller \& Zavaleta, 2009; Rüdisser et al., 2012). For this reason, under the circumstance of changing climate and land use transformations, migration, the flow of individuals and/or colonization between neighbouring sites could be prohibited and inevitably increase species extinction risk. This is because structural and functional connectivity between habitat patches are vital to determine their adaptation and resilience to global climate change and human pressures (Heller \& Zavaleta, 2009; Mazaris et al., 2013).

In this case, Sungai Dusun was once the only reserve in Peninsular Malaysia that set aside for the protection of the rare and critically endangered Sumatran rhinoceros (Dicerorhinus sumatrensis) (DWNP 2004). Nevertheless, recent study shown no evidence of free-ranging rhinoceros within Sungai Dusun and nearby forest reserves (e.g. Sungai Karang Forest Reserve and Raja Musa Forest Reserve) (Sasidhran et al. 2016). Havmøller et al. (2015) suggested that this species was already extinct in the wild in Peninsular Malaysia. Threats that responsible for the species' decline are habitat loss and poaching (Ahmad et al., 2013; Rabinowitz 1995). Mounting agricultural growth surrounding Sungai Dusun probably increased human disturbance and chances for poachers to intrude into the core of the protected areas to hunt for this species.

As a result, lower vegetation cover but higher development or agricultural land, consequently, lack of species diversity to perform some ecological functions may be responsible for the overall lower resilience in the protected areas, especially Klang Gate in this study. The pervasive ability of land use and landscape pattern modification in the urbanizing region probably impose threats of biodiversity loss to the protected areas. Loss of biodiversity or its associated elements (i.e., ecological structure and function) would indicate a lack of resilience during the time of pressure on ecosystems and natural resources (Cumming et al., 2005). In this study, Klang Gate which used to be called as a habitat island by ecologists (Perumal, 1992; Wong et al., 2010) (i.e., supported some endemic plant species and endangered animal, Sumatran serow at the quartz ridge) is currently severely encroached by human development. The persistence of these endemic and endangered species within the protected areas remain uncertain. Hence, we believe that urban protected area landscape with 
more diverse and heterogeneous vegetation nearby are possibly more likely to maintain higher resilience than isolated protected area without supplement from the surrounding natural habitat. Asensio et al. (2009) publicised that howler monkeys used several landscape elements outside their home patch, such as isolated trees, live fences and neighbouring forest patches to supplement their diet, and eventually provide a possible extension to their home range.

For this reason, we suppose ecosystem resilience in Selangor state receiving a warning sign from the results of lower resilience level of some protected areas throughout the study period. To maintain ecosystem resilience of the region, protected areas systems and their neighbouring social systems play a very critical role. Apart from land use development and policy, the other sources of change exert on protected area systems including extreme events or disaster, or political and economic change. Therefore, conservation of protected areas as an individual entity and kept as wilderness areas may not feasible and sustainable for the rapidly developing countries like Malaysia. To date, protected areas should be created and publicized as a complex social-ecological system that is both maintained and driven by the dynamics and interactions of their human and ecological elements - retain the conservation biodiversity as their core in the midst of changing social context (Cumming et al. 2016). To maintain the effectiveness and resilience of protected areas, contemporary conservation policies should integrate ecosystem around the protected areas and gradually extend conservation efforts to encompass a much greater variety of protected area types and protection agreements.

\section{CONCLUSION}

Protected areas in urbanizing Selangor State are highly pressured and vulnerable to land development for residential and commercial uses. Depending on protected areas alone in biodiversity conservation of urbanizing region is an over-optimistic approach. The effects of urbanization could be very significant when close to urban areas and then decline after some distance (Mcdonald et al., 2009). In comparison with Bukit Kutu and Sungai Dusun, Klang Gate located closer to the heart of development, which is the city centre and eventually more susceptible to development pressures. The greater extent of a landscape pattern change and increasing human settlement established on the inside and outside of Klang Gate apparently indicated the ecological integrity and capacity to absorb the disturbance regime declined for the past two decades. The outcomes of this study have far-reaching implications for future management planning and conservation strategies as they showed that the protected areas experience degradation and ineffective protection of their boundaries from unsustainable development. The findings of these three reserves can be a reference for policy planner or other interest bodies in decision making for future land use planning.

The interpretation of this study also leads to a profound reconsideration of the management and governance of protected areas and their surroundings to achieve sustainable development. Therefore, an alternative way to accomplish this and maintain urban ecosystem resilience is through the integration of the management of protected areas into part of a broader ecosystem instead of managing them in isolation from the surrounding areas (Hansen \& Defries, 2007b; Martinuzzi et al., 2015). In urban planning and management, different types of urban green patches in close proximity to the protected areas can be clustered and managed together to ease the habitat-use by different species (Colding, 2007), for instances orchard land, urban garden, shrub and arboretum. Nevertheless, these approaches require actions and collaborations from many levels, including individual (e.g. home and landowners), local and regional government, non-governmental organisation, 
Lee W. H., Abdullah S.A., Nor S.B.M.: Land use and landscape pattern changes on the inside and outside of protected areas in urbanizing Selangor State, Peninsular Malaysia

ecologists and federal agencies. A paradigm shift in the approach to natural resource management is required especially in developing countries like Malaysia.

Before it happens, more scientific and explicit studies and evidence are necessary to convince different stakeholders to apply more sustainable conservation management that accentuates conservation beyond boundaries. More researches on the current conservation and development policies are inevitably essential to provide a future dimension and improvement on conservation efforts. Analyses on subsequent trajectories on urban and suburban development are also the crucial data to articulate next conservation plan. Furthermore, a conservation blueprint on the connectivity of all the protected areas and other natural vegetation surrounding them in the urbanizing region is critical before all these green spaces are converted to other land use purposes.

\section{ACKNOWLEDGEMENT}

We are very thankful for the financial support in terms of the scholarship received by the first author from program MyBrain 15 by the Ministry of Higher Education (MoHE). The authors are grateful to receive assistance from officers of the Department of Wildlife and National Parks (DWNP) and other PhD candidates from LESTARI, UKM.

\section{REFERENCE}

Abdullah, S. A. \& Hezri, A. A. (2008). From forest landscape to agricultural landscape in the developing tropical country of Malaysia: Pattern, process, and their significance on policy. Environmental Management, 42, 907-917. https://doi.org/10.1007/s00267 -008-9178-3.

Adila, N., Sasidhran, S., Kamarudin, N., Puan, C. L., Azhar, B. \& Lindenmayer, D. B. (2017). Effects of peat swamp logging and agricultural expansion onspecies richness of native mammals in Peninsular Malaysia. Basic and Applied Ecology, 22, 1-10.

Ahmad, A. H., Payne, J. \& Zainuddin, Z. Z. (2013). Preventing the extinction of the Sumatran rhinoceros. Journal of Indonesian Natural History, 1, 11-22.

Alberti, M. \& Marzluff, J. M. (2004). Ecological resilience in urban ecosystems: Linking urban patterns to human and ecological functions. Urban Ecosystems, 7, 241-265.

Andren, H. (1994). Effects of habitat fragmentation on birds and mammals with different proportions of suitable habitat: a review. Oikos, 71(3), 355-366.

Asensio, N., Arroyo-Rodriguez, V., Dunn, J. C. \& Crisobal-Azkarate, J. (2009). Conservation value of landscape supplementation for howler monkeys living in forest patches. Biotropica, 41: 768-773. https://doi.org/10.1111/j.1744-7429.2009.00533.x.

Bailey, K. M., Mccleery, R. A., Binford, M. W., Zweig, C. (2016). Land-cover change within and around protected areas in a biodiversity hotspot. Journal of Land Use Science, 11(2), 154-176.

Blair, R. (2004). The effects of urban sprawl on birds at multiple levels of biological organization. Ecology and Society, 9(5), 2.

Bogaert, J., Barima, Y. S. S., Mongo, W., Bamba, I., Mama, A., Toyi, M. \& Lafortezza, R. (2011). Forest Fragmentation: Causes , Ecological Impacts and Implications for Landscape Management. In C. Li, R. Lafortezza, \& J. Chen (Eds.), Landscape Ecology in Forest 
Management and Conservation (pp. 273-296). New York: Springer, Berlin, Heidelberg.

Bunnell, T. \& Barter, P. A. (2002). Kuala Lumpur metropolitan area. Cities, 19(5), 357-370.

Butchart, S. H. M., Scharlemann, J. P. W., Evans, M. I., Quader, S., Aricò, S., Arinaitwe, J., Balman, M., Bennun, L. A., Bertzky, B., Besançon, C., Boucher, T. M., Brooks, T. M., Burfield, I. J., Burgess, N. D., Chan, S., Clay, R. P., Crosby, M. J., Davidson, N. C., De Silva, N., Devenish, C., Dutson, G. C. L., Fernández, D. D. F., Fishpool, L. D. C., Fitzgerald, C., Foster, M., Heath, M. F., Hockings, M., Hoffmann, M., Knox, D., Larsen, F.W., Lamoreux, J. F., Loucks, C., May, I., Millett, J., Molloy, D., Morling, P., Parr, M., Ricketts, T. H., Seddon, N., Skolnik, B., Stuart, S. N., Upgren, A. \& Woodley, S. (2012). Protecting important sites for biodiversity contributes to meeting global conservation targets. PLoS ONE, 7(3), e32529. https://doi.org/10.1371/journal.pone.0032529.

Butt, A., Shabbir, R., Ahmad, S. S. \& Aziz, N. (2015). Land use change mapping and analysis using remote sensing and GIS: A case study of Simly watershed, Islamabad, Pakistan. The Egyptian Journal of Remote Sensing and Space Sciences, 18(2), 251-259. http://dx.doi.org/10.1016/j.ejrs.2015.07.003.

Castro-prieto, J., Martinuzzi, S., Radeloff, V. C., Helmers, D. P., Quiñones, M. \& Gould, W. A. (2017). Declining human population but increasing residential development around protected areas in Puerto Rico. Biological Conservation, 209, 473-481.

Clay, E., Moreno-Sanchez, R., Torres-Rojo, J. M. \& Moreno-Sanchez, F. (2016). National assessment of the fragmentation levels and fragmentation-class transitions of the forests in Mexico for 2002, 2008 and 2013. Forests, 7(3), 6-8. https://doi.org/10.3390/f7030048.

Cohen, J. (1960). A coefficient of agreement for nominal scales. Educational and Psychological Measurement, 20(1), 37-46.

Colding, J. (2007). "Ecological land-use complementation" for building resilience in urban ecosystems. Landscape and Urban Planning, 81, 46-55. https://doi.org/10.1016/ j.landurbplan.2006.10.016.

Cumming, G. S., Barnes, G., Perz, S., Schmink, M., Sieving, K. E., Southworth, J., Binford, M., Holt, R. D., Stickler, C. \& Van Holt, T. (2005). An exploratory framework for the empirical measurement of resilience. Ecosystems, 8, 975-987.

Cumming, G. S. (2016). The relevance and resilience of protected areas in the Anthropocene. Anthropocene, 13, 46-56.

Defries, R., Hansen, A., Turner, B. L., Reid, R. \& Liu, J. (2007). Land use change around protected areas: management to balance human needs and ecological function. Ecological Function, 17(4), 1031-1038. https://doi.org/10.1890/05-1111.

Dudley, N. \& Stolton, S. (2008). Defining protected areas: An international conference in Almeria, Spain Mayo 2007. Gland, Switzerland: IUCN.

DWNP. (2004). Sungai Dusun Wildlife Reserve Development and Management Plan. Kuala Lumpur: UPM \& DWNP.

Eastman, J. R. (2001). Idrisi 32 Release 2 Guide to GIS and Image Processing Volume 1. Worcester: Clark University (Vol. 1). Worcester, MA: Clark University.

ERDAS Inc. (1999). ERDAS Field Guide. $5^{\text {th }}$ edition. Atlanta, Georgia: ERDAS ${ }^{\circledR}$, Inc.

Estevo, C. A., Nagy-reis, M. B. \& Silva, W. R. (2017). Urban parks can maintain minimal resilience for Neotropical bird communities. Urban Forestry \& Urban Greening, 27, 84-89.

Estreguil, C. \& Mouton, C. (2009). Measuring and reporting on forest landscape pattern, fragmentation and connectivity in Europe: methods and indicators. Italy: JRC Scientific and 
Lee W. H., Abdullah S.A., Nor S.B.M.: Land use and landscape pattern changes on the inside and outside of protected areas in urbanizing Selangor State, Peninsular Malaysia

Technical Reports Office for Official, pp 7-8.

European Commission. (2019). GuidosToolbox (GTB). Retrieved December 20, 2017, from https://forest.jrc.ec.europa.eu/en/activities/lpa/gtb/.

Fahrig, L. (2003). Effects of habitat fragmentation on biodiversity. Annual Review of Ecology, Evolution, and Systematics, 34, 487-515. https://doi.org/10.1146/annurev.ecolsys. 34.011802.132419.

Fu, B. J., Hu, C. X., Chen, L. D., Honnay, O. \& Gulinck, H. (2006). Evaluating change in agricultural landscape pattern between 1980 and 2000 in the Loess hilly region of Ansai County, China. Agriculture, Ecosystems and Environment, 114, 387-396. https://doi.org/ 10.1016/j.agee.2005.11.012.

Gallant, A. L., Loveland, T. R., Sohl, T. L. \& Napton, D. E. (2004). Using an ecoregion framework to analyze land-cover and land-use dynamics. Environmental Management, 34(S1), S89-S110.

Hansen, A. J., Knight, R. L., Marzluff, J. M., Powell, S., Brown, K., Gude, P. H. \& Jones, K. (2005). Effects of exurban development on biodiversity: patterns, mechanisms, and research needs. Ecological Applications, 15(6), 1893-1905.

Hansen, A. J. \& Defries, R. (2007a). Ecological mechanisms linking protected areas to surrounding lands. Ecological Applications, 17, 974-988.

Hansen, A. J. \& Defries, R. (2007b). Land use change around nature reserves: implications for sustaining biodiversity. Ecological Applications, 17(4), 972-973.

Hassan, M. M. (2017). Monitoring land use/land cover change, urban growth dynamics and landscape pattern analysis in five fastest urbanized cities in Bangladesh. Remote Sensing Applications: Society and Environment, 7, 69-83. http://dx.doi.org/ 10.1016/j.rsase.2017.07.001.

Havmøller, R.G., Payne, J., Ramono, W., Ellis, S., Yoganand, K., Long, B., Dinerstein, E., Williams, A.C., Putra, R.H., Gawi, J., Talukdar, B.K. \& Burgess, N., 2015. Will current conservation responses save the critically endangered Sumatran rhinoceros Dicerorhinus sumatrensis? Oryx, 50, 1-5.

Heller, N. E. \& Zavaleta, E. S. (2009). Biodiversity management in the face of climate change: a review of 22 years of recommendations. Biological Conservation, 142, 14-32.

Hill, J. K., Gray, M. A, Khen, C. V., Benedick, S., Tawatao, N. \& Hamer, K. C. (2011). Ecological impacts of tropical forest fragmentation: how consistent are patterns in species richness and nestedness? Philosophical Transactions of the Royal Society of London. Series B, Biological Sciences, 366, 3265-3276. doi: 10.1098/rstb.2011.0050.

Ho, C. S. (2008). Urban governance and rapid urbanization issues in Malaysia. Jurnal Alam Bina, 13(4), 1-24.

Holling, C. S. (1973). Resilience and stability of ecological systems. Annual Review of Ecology and Systematics, 4, 1-23.

Islam, K., Jashimuddin, M., Nath, B. \& Nath, T. K. (2018). Land use classification and change detection by using multi-temporal remotely sensed imagery: The case of Chunati wildlife sanctuary, Bangladesh. The Egyptian Journal of Remote Sensing and Space Sciences 2, 37-47.

IUCN. (2005). Benefits Beyond Boundaries. Proceedings of the Vth IUCN World Parks Congress. Gland, Switzerland and Cambridge, UK: IUCN. 
Landis, J. R. \& Koch, G. G. (1977). The measurement of observer agreement for categorical data. Biometrics, 33(1), 159-174.

Lee, W. H. \& Abdullah, S. A. (2019). Framework to develop a consolidated index model to evaluate the conservation effectiveness of protected areas. Ecological Indicators, 102, 131-144.

Leroux, S. J. \& Kerr, J. T. (2012). Land development in and around protected areas at the wilderness frontier. Conservation Biology, 27(1), 166-176. doi: 10.1111/j.15231739.2012.01953.x.

Lim, B. L., Majid, R. A. \& Norsham, Y. (1999). Studies on the mammal fauna of Bukit Kutu Wildlife Reserve, Hulu Selangor. Journal of Wildlife and Parks, 17, 1 - 16.

Lynam, A. J. (2010). Securing a future for wild Indochinese tigers: transforming tiger vacuums into tiger source sites. Integrative Zoology, 5, 324-334.

Martinuzzi, S., Radeloff, V. C., Joppa, L. N., Hamilton, C. M., Helmers, D. P., Plantinga, A. J. \& Lewis, D. J. (2015). Scenarios of future land use change around United States' protected areas. Biological Conservation, 184, 446-455.

Mascia, M. B., Pailler, S., Krithivasan, R., Roshchanka, V., Burns, D., Mlotha, M. J., Murray, D. R. \& Peng, N. (2014). Protected area downgrading, downsizing, and degazettement (PADDD) in Africa, Asia, and Latin America and the Caribbean, 1900-2010. Biological Conservation, 169, 355-361.

Masron, T., Yaakob, U., Ayob, N. M. \& Mokhtar, A. S. (2012). Population and spatial distribution of urbanisation in Peninsular Malaysia 1957 - 2000. Geografia: Malaysia Journal of Society and Space, 8(2), 20-29.

Mazaris, A. D., Papanikolaou, A. D., Barbet-Massin, M., Kallimanis, A. S., Jiguet, F., Schmeller, D. S. \& Pantis, J. D. (2013). Evaluating the connectivity of a protected areas' network under the prism of global change: the efficiency of the European Natura 2000 network for four birds of prey. PLoS One, 8, e59640.

Mcdonald, R. I., Kareiva, P. \& Forman, R. T. T. (2008). The implications of current and future urbanization for global protected areas and biodiversity conservation. Biological Conservation, 141, 1695-1703.

Mcdonald, R. I., Forman, R. T. T., Kareiva, P., Neugarten, R., Salzer, D. \& Fisher, J. (2009). Urban effects, distance, and protected areas in an urbanizing world. Landscape and Urban Planning, 93, 63-75.

McDonnell, M. J. \& Stiles, E. W. (1983). The structural complexity of old field vegetation and the recruitment of bird-dispersed plant species. Oecologia, 56, 109-116.

Mckinney, M. L. (2002). Urbanization, biodiversity, and conservation. BioScience, 52(10), 883-890.

Mcpherson, E. G., Grimmond, S. U. E. \& Souch, C. (1997). Quantifying urban forest structure, function, and value: the Chicago Urban Forest Climate Project. Urban Ecosystems, $1,49-61$.

Olaniyi, A. O., Abdullah, A. M., Ramli, M. F. \& Soods, A. M. 2013. Agricultural land use in Malaysia: an historical overview and implications for food security. Bulgarian Journal of Agricultural Science, 19(1), 60-69.

Pattanavibool, A. \& Dearden, P. (2002). Fragmentation and wildlife in montane evergreen forests, northern Thailand. Biological Conservation, 107, 155-164.

Perumal, B. (1992). Management survey of Klang Gates Wildlife Sanctuary. Petaling Jaya: 
Lee W. H., Abdullah S.A., Nor S.B.M.: Land use and landscape pattern changes on the inside and outside of protected areas in urbanizing Selangor State, Peninsular Malaysia

WWF Malaysia.

Pfeifer, M., Lefebvre, V., Peres, C. A., Banks-Leite, C., Wearn, O. R., Marsh, C. J., Butchart, S. H. M., Arroyo-Rodríguez, V., Barlow, J., Cerezo, A., Cisneros, L., D’Cruze, N., Faria, D., Hadley, A., Harris, S. M., Klingbeil, B. T., Kormann, U., Lens, L., Medina-Rangel, G. F., Morante-Filho, J. C., Olivier, P., Peters, S. L., Pidgeon, A., Ribeiro, D. B., Scherber, C., Schneider-Maunoury, L., Struebig, M., Urbina-Cardona, N., Watling, J. I., Willig, M. R., Wood, E. M. \& Ewers, R. M. (2017). Creation of forest edges has a global impact on forest vertebrates. Nature, 551, 187-191.

Rabinowitz, A. (1995). Helping a species go extinct: the Sumatran rhino in Borneo. Conservation Biology, 9, 482-488.

Razak, K. A., Mohamad, Z., Ibrahim, M. Z., Rosle, Q. A., AbdWahab, M. H., Bakar, R. A. \& Akib, W. A. A. M. (2015). Geospatializing the Klang Gate quartz ridge in Malaysia: a technological perspective. Geophysical Research Abstracts, 17, EGU2015-8368.

Reza, M. I. H., Abdullah, S. A., Nor, S. M. \& Ismail, M. H. (2013). Integrating GIS and expert judgment in a multi-criteria analysis to map and develop a habitat suitability index: A case study of large mammals on the Malayan peninsula. Ecological Indicators, 34, 149-158.

Reza, M. I. H. (2014). Measuring forest fragmentation in the protected area system of a rapidly developing Southeast Asian tropical region. Science Postprint, 1(1), e00030. doi:10.14340/spp.2014.09A0001.

Riitters, K. H., Wickham, J. D., Neill, R. V. O., Jones, K. B., Smith, E. R., Coulston, J. W., ... Smith, J. H. (2002). Fragmentation of continental United States forests. Ecosystems, 5, 815-822.

Rivard, D. H., Poitevin, J., Plasse, D., Carleton, M. \& David, J. (2000). Changing species richness and composition in Canadian National Parks. Conservation Biology, 14(4), 1099-1109. https://doi.org/10.1046/j.1523-1739.2000.98247.x.

Rüdisser, J., Tasser, E. \& Tappeiner, U. (2012). Distance to nature - A new biodiversity relevant environmental indicator set at the landscape level. Ecological Indicators, 15, 208-216.

Rutledge, D. (2003). Landscape indices as measures of the effects of fragmentation: can pattern reflect process? Wellington: Deaprtment of Conservation. https://doi.org/10.1007/s10980-011-9650-y.

Sasidhran, S., Adila, N., Hamdan, M.S., Samantha, L.D., Aziz, N., Kamarudin, N., Chong, L.P., Turner, E. \& Azhar, B. 2016. Habitat occupancy patterns and activity rate of native mammals in tropical fragmented peat swamp reserves in Peninsular Malaysia. Forest Ecology and Management, 363, 140-148.

Sauders, D. A., Hobbs, R. J. \& Margules, C. R. (1991). Biological consequences of ecosystem fragmentation: A review. Conservation Biology, 5, 18-32.

Savard, J. L., Clergeau, P. \& Mennechez, G. (2000). Biodiversity concepts and urban ecosystems. Landscape and Urban Planning, 48, 131-142. https://doi.org/10.1016/ S0169-2046(00)00037-2.

Shaharum, N. S. N., Shafri, H. Z. M., Gambo, J. \& Abidin, F. A. Z. (2018). Mapping of Krau Wildlife Reserve (KWR) protected area using Landsat 8 and supervised classification algorithms. Remote Sensing Applications: Society and Environment, 10, 24-35.

Sicuriello, F., De Nicola, C., Dowgiallo, G. \& Testi, A. (2014). Assessing the habitat conservation status by soil parameters and plant ecoindicators. iForest, 7, 170-177. 
Soille, P. \& Vogt, P. (2009). Morphological segmentation of binary patterns. Pattern Recognition Letters, 30, 456-459.

Steinhardt, U., Herzog, F., Lausch, A., Müller, E. \& Lehmann, S. (1999). Hemeroby index for landscape monitoring and evaluation. In Y. A. Pykh, D. E. Hyatt, \& R. J. Lenz (Eds.), Environmental Indices - System Analysis Approach (pp. 237-254). Oxford, UK: EOLSS Publishers Co. Ltd.

Tee, S. L., Samantha, L. D., Kamarudin, N., Akbar, Z., Lechner, A. Z., Ashton-Butt, A. \& Azhar, B. (2018). Urban forest fragmentation impoverishes native mammalian biodiversity in the tropics. Ecology and Evolution, 8, 12506-12521.

Terra, T. N., dos Santos, R. F. \& Costa, D. C. (2014). Land use changes in protected areas and their future: The legal effectiveness of landscape protection. Land Use Policy, 38, 378-387. http://dx.doi.org/10.1016/j.landusepol.2013.12.003.

Trzyna, T. (2014). Urban Protected Areas: Profiles and best practice guidelines. Gland, Switzerland: IUCN.

Viera, A. J. \& Garrett, J. M. (2005). Understanding interobserver agreement: The kappa statistic. Family Medicine, 37(5), 360-363.

Vogt, P. (2015). Quantifying landscape fragmentation. In P. de Rosto \& D. Catalográficos (Eds.), Anais XVII Simpósio Brasileiro de Sensoriamento Remoto - SBSR, João Pessoa-PB, Brasil, 25 a 29 de abril de 2015, INPE (pp. 1239-1246). https://doi.org/10.1017 /CBO9781107415324.004.

Walz, U. \& Stein, C. (2014). Indicators of hemeroby for the monitoring of landscapes in Germany. Journal for Nature Conservation, 22, 279-289.

Wei, D., Luo, Z., Li, J., Wang, W. \& Zhang, M. (2015). Assessing the effectiveness of protecting reserves for nature assets in China. Journal of Geographical Sciences, 25(4), 417-427.

Wickham, J. D., Riitters, K. H., Wade, T. G. \& Vogt, P. (2010). A national assessment of green infrastructure and change for the conterminous United States using morphological image processing. Landscape and Urban Planning, 94, 186-195. https://doi.org/10.1016/ j.landurbplan.2009.10.003.

Wong, K. M., Sugumaran, M., Lee, D. K. P. \& Zahid, M. S. (2010). Ecological aspects of endemic plant populations on Klang Gates quartz ridge, a habitat island in Peninsular Malaysia. Biodiversity and Conservation, 19(2), 435-447. https://doi.org/10.1007 /s10531-008-9522-1.

Yaakob, U., Masron, T. \& Masami, F. (2012). Ninety years of urbanization in Malaysia: A geographical investigation of its trends and characteristics. Journal of Ritsumeikan Social and Humanities, 4, 79-101. 